
Constitution

Richard Kay

Follow this and additional works at: https://opencommons.uconn.edu/law_papers

Part of the Constitutional Law Commons

Recommended Citation

Kay, Richard, "Construction, Originalist Interpretation and the Complete Constitution" (2017). Faculty Articles and Papers. 511.

https://opencommons.uconn.edu/law_papers/511 


\title{
CONSTRUCTION, ORIGINALIST INTERPRETATION AND THE COMPLETE CONSTITUTION
}

\begin{abstract}
Richard S. Kay*
In recent years, the literature of constitutional originalism has adopted a new concept, "constitutional construction." This Essay critically examines that concept. Contrary to some claims, the difference between "interpretation" and "construction" is not well established in common law adjudication. Contemporary descriptions of constitutional construction end up leaving some ill-defined discretion in the hands of constitutional decision-makers. Finally, the Essay disputes the claim that constitutional construction is unavoidable because the constitutional text is inherently incomplete. It fails to provide a decision-rule for manyindeed for most - constitutional disputes. This conclusion follows, however,only when the Constitution is interpreted according to the "new" or "public meaning" version of originalism. At least in the context of constitutional adjudication, originalist interpretation seeking to identify the meaning of the text that was actually intended by the people whose assent made it law, leaves no indeterminate constitutional controversies. In every argument about the application of a constitutional provision to an actual dispute, one side's interpretation will always better conform to that original meaning. In that sense, at least, the Constitution is complete.
\end{abstract}

\section{INTRODUCTION}

In the last few years the literature of originalist constitutional interpretation and application has featured a new concept_-" constitutional construction." Construction has been distinguished from constitutional interpretation more strictly defined. ${ }^{1}$ Lawrence Solum, one of its most prolific proponents, explains the distinction this way:

"Constitutional interpretation" is the activity that discerns the communicative content (linguistic meaning) of the constitutional text. "Constitutional con-

* Wallace Stevens Professor of Law Emeritus and Oliver Ellsworth Research Professor, University of Connecticut School of Law. I am grateful to James Allan, Mitchell Berman, Saul Cornell, Jeffrey Goldsworthy, Alexandra Lahav, Michael Perry and Eric Segall for valuable comments.

1 See, e.g., William Baude, Is Originalism Our Law?, 115 Colum. L. Rev. 2349, 2357-58 (2015) (characterizing construction as an "accessory to interpretation"); Curtis A. Bradley and Neil S. Siegel, Constructed Constraint and the Constitutional Text, 64 DUKE LJ. 1213, 1269 (2015) (distinguishing between construction and interpretation); Gary Lawson, Classical Liberal Constitution or Classical Liberal Construction?, 8 N.Y.U. J.L. \& LIBERTY 808, 814 (2014) (claiming that it is now the "standard" to differentiate between construction and interpretation). See generally Symposium, The New Originalism in Constitutional Law, 82 FORDHAM L. REV. 371 (2013) (discussing the methods of constitutional interpretation, and examining the possibility that "constitutional construction theory" has become a "supplement to interpretation"); Symposium, The Interpretation/Construction Distinction in Constitutional Law 27 CONST. COMMENT. 1 (2010) (exploring the "implications of the interpretation-construction distinction"). 
struction" is the activity that determines the content of constitutional doctrine and the legal effect of the constitutional text. ${ }^{2}$

Interpretation and construction, that is, correspond to two different moments in the process of any decision controlled by an authoritative legal text. The text describes some set of facts and the consequences that should follow when those facts obtain. The first stage of decision, interpretation, is the process of apprehending the nature of the posited state of affairs and the designated consequences. In the second stage, construction, the decision-maker, armed with this understanding, determines if the rule so interpreted applies to a particular concrete situation and, if so, what actions must be taken to effect the appropriate consequences.

It is hard to deny the conceptual distinctness of these two kinds of activities. $^{3}$ More controversial is the further claim that construction, the production of the "juridical meaning . . . authorized by the legal text," may not be fully determined by the contents of that text. A determinate construction, that is, does not always follow automatically from a given interpretation. A critical premise of this conclusion is that the text cannot, by itself, supply answers in many constitutional controversies. In these cases, says Keith Whittington, the act of construction necessarily "involve[s] judgments and choices about how best to resolve. . .[textual] indeterminacies." On some occasions, therefore, in some circumstances and at least to some extent, constitutional construction is independent of the constitutional text. This Essay disputes the essential premise on which this reasoning is based. For the purposes of constitutional adjudication, the Constitution is complete. It is always sufficient to identify the better argument in litigated constitutional cases. Constitutional construction, therefore, is as unnecessary as it is in tension with the purposes of constitutional government.

Part I reviews the claim that the distinction between the interpretation and construction of texts has been a common and well-established legal

2 Lawrence B. Solum, Originalism and Constitutional Construction, 82 FORDHAM L. REV. 453, 457 (2013) (hereinafter Solum, Originalism). See also Randy E. Barnett, Interpretation and Construction, 34 HARV. J.L. \& PUB. POL'Y. 65, 66 (2011) (hereinafter Barnett, Interpretation) ("Interpretation is the activity of identifying the semantic meaning of a particular use of language in context. Construction is the activity of applying that meaning to particular factual circumstances.").

3 There is reason to doubt that, in practice, there is any clear temporal separation between interpretation and application. Understanding will often unfold in the course of application. Solum properly points out that the two conceptually distinct stages will appear to collapse in cases in which the meaning of the relevant text is clear and unambiguous on its face. Lawrence B. Solum, The Interpretation-Construction Distinction, 27 CONST. COMMENT. 95, 117-18 (2010) (hereinafter Solum, Interpretation-Construction).

4 Keith E. Whittington, Constructing a New American Constitution, 27 CONST. COMMENT. 119, 122 (2010) (hereinafter Whittington, Constructing.) 
concept "for the last two centuries." Part II describes how constitutional construction has been explained and applied by its academic defenders. It concludes that construction-as it appears in the current literature-leaves a wide discretion to officials and especially to judges employing it. Part III critically examines the claim that construction is unavoidable because legal texts are inherently incomplete, so mere interpretation of the Constitution cannot yield an answer to every disputed question about its proper application. Therefore, something else, something like constitutional construction, is necessary to resolve those disputes. This reasoning makes sense but only when coupled with a particular version of originalist interpretation, one that has as its object the "original public meaning" of the Constitution at the time of enactment. I show that this reasoning is unwarranted if we adopt an alternative understanding of originalist interpretation, one that seeks the meaning of the constitutional rules that was actually intended by the people whose decisions made the Constitution law. Understood that way, the Constitution is, at least in the context of constitutional litigation, complete: It will always be possible to find that one party's interpretation of the Constitution better fits the original meaning than the other's.

\section{AN “ANCIENT” DISTINCTION}

Recent expositions of constitutional construction have sometimes described and defended it as a well-established American legal practice. They have also insisted that the separate meanings of "construction" and "interpretation" are of "ancient vintage." " Until the appearance of the recent academic literature on construction, however, "construction" and "interpretation" have almost always been used interchangeably. In a recent decision, for example, the United States Supreme Court casually treated the two terms as referring to the same process: "As with all statutory interpretation questions, construction of [legislation] must begin with the plain language of the statute." 7

It is true that as far back as the first half of the nineteenth century, one can find academic commentary as well as some judicial opinions that use these terms in a way similar to that described above. But these cases are

5 E.g., Lawrence Solum, Graber on the Interpretation-Construction Distinction Panel at the AALS, LEGAL THEORY BLOG, http://solum.typepad.com/legaltheory/2010/01/graber-on-theinterpretationconstruction-distinction-panel-at-the-aals.html (Jan. 13, 2010).

6 Barnett, Interpretation at 65.

7 Negusie v. Holder, 555 U.S. 511, 542 (2009) (Thomas, J., dissenting). See also Miller v. French, 530 U.S. 327, 358 (2000) (Breyer, J., dissenting) (asking if a certain "interpretation" was a "reasonable construction" of a statute, essentially treating the two terms as interchangeable); ANTONIN SCALIA \& BRYAN A. GARNER, READING LAW: THE INTERPRETATION OF LEGAL TEXTS 13-15 (2012) (acknowledging the distinction between interpretation and construction in academic discourse, but pointing out that the Court has yet to adopt this distinction). 
rare. Far more prevalent has been the use of these two words as synonyms. Almost all of the exceptions, moreover, are traceable to a single and highly idiosyncratic source, Francis Lieber's 1839 treatise, Legal and Political Hermeneutics. ${ }^{8}$ The first, 1920, edition of Samuel Williston's treatise on The Law of Contracts compared interpretation, seeking "the sense which [the] author intended to convey" with construction, the "drawing of conclusions "in the spirit though not the letter of the text." Williston's principal authority was Lieber. ${ }^{9}$ The first, 1891, edition of Sutherland's Statutes and Statutory Construction noted the difference between construction and interpretation, but only in connection with "Dr. Lieber's definition," and mainly as a warning against departing from the legislature's expressed intentions based on some "extraneous consideration or theory of construction." 10 When we turn to testamentary instruments (where the distinct uses of construction and interpretation most clearly persist $)^{11}$ we see much the same thing. William Page's 1901 A Concise Treatise on the Law of Wills agrees that "[i]n the most technically accurate use of language Construction should probably be distinguished from... Interpretation" and quotes Lieber's definitions. ${ }^{12}$ Like Sutherland, however, Page found these "philosophical" usages "cut[] sharply across the distinctions and classifications which have in the past in actual practice been observed by the courts. ..;" therefore, he gave them no further attention. ${ }^{13}$

Francis Lieber, the instigator of this terminology, was a German immigrant who became a prominent nineteenth century authority in numerous fields of American law. According to Paul Carrington, when Lieber died in 1872 , he was "without serious question the most eminent legal scholar in

8 Francis LIEBER, LEGAL AND POLITICAL HERMENEUTICS (1839) (Legal Classics Library ed. 1994).

9 SAMUEl Williston, THE LAW OF CONTRACTS 1159-60 and note 3. Williston also cited ("see also") 2 William F. ElliotT, COMMENTARIES ON THE LAW OF CONTRACTS s. 1505 (1913). Elliott's meaning, however, was quite different. He used the term "construction" to emphasize the need to take into account "the whole transaction" in order to give effect to the contract that the parties "intended to make and upon which their minds met." Williston went on to say that the distinction between interpretation and construction is "of no legal consequence" in the law of contracts.

10 J. G. SuTHERland, StatuTES AND STATUTORy CONSTRUCTION 311-12 (1891)

11 Restatement (Third) OF Property: Wills and Other Donative Transfers s. 11.3, Comment c. (2000) (describing interpretation as "the process of searching for the donor's actual intention" and construction as "designat[ing] the final product of the process of determining the meaning" but insisting they are "not completely distinct processes . . nor are they applied sequentially.") In contrast, the drafters of the first Restatement apparently wished to distinguish construction (the judicial ascertainment of the "intent of the conveyor") from the "ascertainment of the effect of an instrument in light of controlling rules of law." That Restatement eschewed the word interpretation altogether, leaving the term to questions associated with the meaning of contracts, while acknowledging that, for the most part, "the two words are identical in meaning." 3 RESTATEMENT OF THE LAW OF PROPERTY S. 241, COMMENTS C. AND E. (1940).

12 William Herbert Page, A CONCISE Treatise on the LaW OF WILls, 533 (1901).

13 Id. at 533-34. 
America."14 When we look at just what Lieber meant by construction, however, we find a hodge-podge of activities related to legal texts. The only unifying thread seems to be that each of the several kinds of "construction" involved judicial correction of textual imperfections. These difficulties covered a range of issues. For example, statutes that were obscure or contained obvious drafting errors were to be repaired with "constructions" that were more in line with the intended goals of the legislation. ${ }^{15}$ This kind of construction, of course, had long been practiced as "interpretation." 16

Lieber, however, also advocated construction to correct errors not of legislative expression but of judgment. Thus he approved the 1835 suggestion of the postmaster-general that post offices should refuse to deliver "incendiary" abolitionist literature even though such a policy was found in "no part of the post law." The postal service, Lieber reasoned, "ought not to aid in destructive measures." 17 This "transcendent construction" was justified on the ground that an apparent meaning had to yield to "a principle superior to the text." 18 The basis of this kind of construction, as the example shows, was an evaluation of social welfare. "The effects, which would result from one or the other construction may guide us in deciding which construction we ought to adopt." 19 A constitutional text, moreover, was not immune to such improvement, "[T] he "public welfare,", he insisted, " is the supremest law of every country, is above the supreme law." 20 Lieber, to be sure, repeatedly warned against possible misuse of "transcendent construction," insisting that it be used infrequently and only when "we have a proper conception of the public welfare." 21 At the end, however, Lieber's descriptions of the various categories of construction provided little guidance to officials charged with implementing binding legal texts. They boiled down to a general injunction to do the right thing, all things considered.

The obscurity of Lieber's notions, however, has turned out to be largely irrelevant. Overwhelmingly, judges and commentators have treated the words "interpretation" and "construction" as referring to the same activity. Lawrence Solum has cited eleven opinions referring to the distinction be-

14 Paul D. Carrington, William Gardiner Hammond and the Lieber Revival, 16 CARDOZO L. REv. 2135, 2144 (1994).

15 LEBER, supra note 8 at 56-57.

16 See e.g., 2A SUTHERLAND STATUTORY CONSTRUCTION $\$ 47: 37$ (7th ed.); Jeffrey Goldsworthy, Constitutional Implications Revisited, 30 U. QUEENSLAND LJ. 9, 13-15 (2011) (examining more traditional forms of "interpretation").

17 LIEBER, supra note 8 at 78-79.

18 Id. at 77 (emphasis supplied).

19 Id. at 144.

$20 I d$. at 181.

21 Id. at 182. 
[Vol. 19:

tween the two terms. These judgments were rendered in seven different courts from 1934 to $1999 .{ }^{22}$ One was a wills case where, as noted, the construction has had a somewhat different history. ${ }^{23}$ The other ten involved the application of contract law. Eight of these ten dealt with the same problem, namely which disputed issues should be treated as questions of fact and which as questions of law. ${ }^{24}$ Nine of the ten contracts cases, moreover, cited Corbin on Contracts as authority for the distinction. The history of the Corbin reference illustrates the failure of the separate usages to take hold. In his first edition, published in 1950, Corbin posited a difference between the interpretation of language and the construction (the "effect upon the action of courts") of contracts. He conceded that "these two words are often used in the same sense," but insisted that "the fact that confused usage is the prevailing usage is not a good reason for adhering to it." None of the cases Corbin cited in that first edition actually employed the distinct senses he defended. ${ }^{25}$ Still, as Solum's cases illustrate, Corbin's adoption of the terminology itself led to its citation in several appellate decisions. ${ }^{26}$ The treatise has now gone through many editions and all of them have repeated the interpretation-construction distinction. The latest edition also dutifully recites it but now it concludes with the statement that "[r]arely do courts articulate this distinction.... Because of this overwhelmingly common practice of courts authoring opinions today, the distinction will not be further discussed in this Volume."27

22 See Solum, Originalism at 486-87. Solum actually lists only nine cases but two of the citations refer to other judgements cited in those decisions.

23 See note 11 supra. Four of the contracts cases were decided in Iowa. Fausel v. JRJ Enterprises, Inc., 603 N.W.2d 612 (Iowa 1999); Grinnell Mut. Reinsurance Co. v. Voeltz, 431 N.W.2d 783 (Iowa 1988); Connie's Constr. Co., Inc. v. Fireman's Fund Ins. Co., 227 N.W.2d 207 (Iowa 1975); Allen v. Highway Equip. Co., 239 N.W.2d 135 (Iowa 1976).

24 Fausel v. JRJ Enterprises, Inc., 603 N.W.2d 612, 618 (Iowa 1999); Grinnell Mut. Reinsurance Co. v. Voeltz, 431 N.W.2d 783, 785 (Towa 1988); Connie's Constr. Co., Inc. v. Fireman's Fund Ins. Co., 227 N.W.2d 207, 210 (Iowa 1975); Allen v. Highway Equip. Co., 239 N.W.2d 135, 139 (Iowa 1976); Berg v. Hudesman, 801 P.2d 222, 226 (Wash. 1990); Ram Const. Co., Inc. v. Am. States Ins. Co., 749 F.2d 1049, 1053 (3d Cir. 1984); Williams v. Humble Oil \& Ref. Co., 432 F.2d 165, 179 (5th Cir. 1970); In re XTI Xonix Technologies Inc., 156 B.R. 821, 829 n.6 (Bankr. D. Or. 1993). The last case notes the distinction between interpretation and construction but it seems to play no role in the decision. In re XTI Xonix, 156 B.R. at 829 n.6. In one of the two other contract cases, the court termed the applicability of the contra proferentem rule a matter of law, one not dependent on the parties' intentions and hence a matter of "construction." Joyner v. Adams, 361 S.E.2d 902, 905 (N.C. App. 1987).

25 See ARTHur L. CORBIN, CORBIN ON CONTRACTS, A COMPREHENSIVE TREATISE ON THE RULES OF CONTRACT LAW, $\$ 534$ (1950).

26 The same may be said, although to a lesser extent, about the somewhat different description of the distinction in Williston's contracts treatise first published in 1920. See text at note 9 supra.

275 CORBIN ON CONTRACTS $\$ 24.3$, pp. 10-11 (1993). Compare Solum, Originalism at 487 ("[T]he distinction is common in American caselaw.") 
The truth, as already noted, is that construction and interpretation have been and continue to be treated as "perfect synonyms." 28 The second edition of Sedgwick's treatise on The Interpretation and Construction of Statutory and Constitutional Law, published in 1874, acknowledged Lieber's categories and "similar discussions [that] have amused the fancy and exhausted the arguments of text writers" but found they "aid us but little in our work." The index entry for "Interpretation, of statutes, treaties etc." was "see "Construction.", 29

\section{What IS CONSTITUTIONAL CONSTRUCTION?}

It is impossible, therefore, to understand the recently elaborated idea of constitutional construction as just a variant of well-defined historical practice. Nailing down its content is further complicated by the fact that the current incarnation has been used in connection with several distinct though overlapping ideas. ${ }^{30}$ In fact, it is not even clear which verb "construction" nominalizes - "construe" or "construct." Randy Barnett says that originalists "need a normative theory for how to construe a Constitution when its meaning runs out." 31 That is also one of the ways thatLieber used the term. ${ }^{32}$ On the other hand, Keith Whittington refers to a meaning that "must be constructed from the political melding of the document with external interests and principles." ${ }_{33}$ The choice is significant insofar as the act of "construing" suggests that the object of the activity is the text itself. A construction then is a version of or implication of a text. "Constructing," on the other hand, suggests the fashioning of something new. ${ }^{34}$ As I will attempt to show, the latter description better fits the creative activity put forward by the academic proponents of constitutional construction. To engage in construction is definitionally to go beyond the constitutional text.

28 Michael Herz, Rediscovering Francis Lieber An Afterword and Introduction, 16 CARDOZO L. REV. 2107, 2128 (1995). See also SCALIA \& GARNER, supra note 7 at 13, 15; Thomas B. Colby, The Sacrifice of the New Originalism, 99 GEO. L. J. 713, 767 (2011). In the Supreme Court, Justice McKenna cited and applied Lieber's usage in two opinions (one a dissent) dealing with the meaning of congressional acts in 1906 and 1907. United States v. Farenholt, 206 U.S. 226, 229230 (1907); Blair v. City of Chicago, 201 U.S. 400,504 (1906), dissenting opinion);

29 THEODORE SEDGWick, A TREATISE ON THE RULES WHich GOVERN THE INTERPRETATION AND CONStruction of Statutory and Constitutional LaW 191, 677 (2d ed. J.N. Pomeroy, ed. 1874).

30 Proliferating academic models of constituteional decision-making have afflicted the concepts of interpretation in general and originalist interpretation in particular. See, e.g., Mitchell N. Berman, Originalism Is Bunk, 84 N.Y.U. L. REV. 1, 4 n.6 (2009).

31 Barnett, Interpretation, supra note 2 at 70.

32 See e.g., LIEBER, supra note 8 at 56.

33 Whittington, Constructing, supra note 4 at 1 . See also SCALIA \& GARNER, supra note 7 at 13.

34 See Whittington, Constructing, supra note 4 at 128 (referring to construction as a "creative task."). 
Constitutional construction is understood to be necessary whenever any person or entity must decide how the Constitution affects a particular situation. Most significant for our purposes, however, is the construction performed by courts in the course of resolving litigated constitutional disputes. These adjudications bind the litigants, including the government. Constructions in cases that are pronounced by the constitutional court of last resort, moreover, are usually taken to bind everyone subject to the constitution in every similar situation. ${ }^{35}$ Judicial constitutional construction, therefore, contributes to the definition of the powers of the state and to the shape of civil society. My focus in this Essay is the extent to which such judicial constitutional construction can be justified given widely shared assumptions about American constitutionalism. First, however, it may be useful to clear the ground by describing two other ways in which the term has been used.

In one influential formulation, constitutional construction signifies choices made by the political branches of government in using or not using the constitutional powers that belong to those branches. ${ }^{36}$ Over time, these choices create a "web of values, institutions, procedures and rights" that takes on normative force. ${ }^{37}$ But the resulting influence on subsequent decisions-unlike the judicial process sketched above - are essentially political not legal. ${ }^{38}$ Such norms are familiar to students of Westminster governments as "constitutional conventions." According to the Supreme Court of Canada, "legal rules create wide powers, discretions and rights which conventions prescribe should be exercised only in a certain limited manner if at all." 39 These conventions are emphatically not rules of law and are not enforceable in courts. ${ }^{40}$ They are "binding" in a political sense but they can be-and sometimes they have been-violated and sometimes abandoned

35 See Cooper v. Aaron, 358 U.S. 1, 18 (1958) (reasoning that the Court's interpretation of the Fourteenth Amendment is by extension the "supreme law of the land"); Larry Alexander \& Frederick Schauer, On Extrajudicial Constitutional Interpretation, 110 HARV. L. REV. 1359 (1997) (defending the primacy of judicial interpretation of the Constitution). The decisions of centralized constitutional courts are usually said to have erga omnes or universal force. See Juliane Kokott \& Martin Kaspar, Ensuring Constitutional Efficacy 795, 814 in THE OXFORD HANDBOOK OF COMPARATIVE CONSTITUTIONAL LAW (Michel Rosenfeld \& Andras Sajo, eds., 2012).

36 Whittington, Constructing at 133.

37 Keith E. Whittington, Constitutional Construction: Divided Powers AND CONSTITUTIONAL MEANING 208 (1999) (hereinafter Whittington, Constitutional CONSTRUCTION).

$38 \quad$ Id. at ix.

39 Re: Resolution to Amend the Constitution, [1981] 1 S.C.R. 753, 881 (reasons of Martland, Ritchie, Dickson, Beetz, Chouinard and Lamer JJ.) See Keith E. Whittington, ConstituTionaL INTERPRETATION 224 (1999)(in the British context, powers may be legally available to the government, but convention may dictate that it is inappropriate to use them)

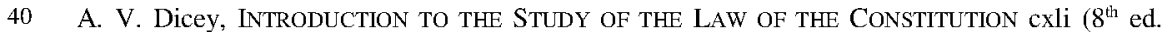
1914, Liberty Classics Reprint 1982). 
by political actors. ${ }^{41}$ If that were all that was meant by constitutional construction, it would have a very limited role in constitutional adjudication. ${ }^{42}$

A second innocuous use of the term, constitutional construction, refers to the application of a constitutional rule to a concrete situation. Randy Barnett describes construction as "the activity of applying [the semantic] meaning [of given language] to particular factual circumstances." ${ }^{43}$ Of course, this supposes we have already identified the "meaning" of the rule. If we know the meaning of a rule, we know what legal consequences ought to follow upon the occurrence of certain facts. Just pronouncing those consequences when the relevant facts present themselves can hardly be controversial. In fact, Lawrence Solum tries to show the ubiquitous quality of construction by describing this situation-when "a court simply translates the semantic content of the text into corresponding legal content and then applies that content to a particular case." When the "legal text is neither ambiguous nor vague," moreover, "the act of construction may go unnoticed since it does no work in determining legal content." It might appear in such an instance that "interpretation does all the work" but that is only because the meaning of the text is so obvious that its application to the facts is inarguable. Even so, "construction is always a step in the process of understanding and applying a legal text. . .."44

If that were all there was to constitutional construction, it would be entirely consistent with conventional ideas about the interpretation and application of legal texts. But, as explained by its proponents, constructions that are far from mechanical will still legally bind. This is apparent in another of Solum's examples of the interpretation-construction sequence: "[W]hen a will violates the rule against perpetuities, a court may give the will a saving construction - this construction gives the will a legal effect that varies from the semantic content of the text." 45 In this case, "construction" is more than the simple application of the meaning of a previously interpreted text. The "saving" construction that allows the will to be given effect is exactly something other than the semantic meaning of the text in question. It is rather the execution of a policy that cannot be inferred solely from the interpreted meaning of the will. In this case, such a reformulation might be mandated by some hierarchically superior "law of wills" that controls how and when wills are to be given effect. Likewise, the common law of con-

41 Id. at 293, 303. For a dramatic example see Paul Scroon, SuRvival For SERvice: My EXPERIENCE AS GOVERNOR GENERAL OF GRENADA 159-60 (2003) (describing exercise of governmental power by the Governor General of Grenada after the American invasion of 1983).

42 See Whittington, CONSTITUTIONAL INTERPRETATION at 205-06 ("[O]riginalism "points out the space fof future constitutional development, without asserting judicial supremacy...”.).

43 Barnett, Interpretation at 66.

44 Solum, Interpretation-Construction at 103 n.19.

45 Id. 
tract has been argued sometimes to require an application of a contract that neither party intended. ${ }^{46}$ In contrast, there is not-there can be no - supraconstitutional law of constitutions, a law that controls and regulates the reach and effect of constitutional texts. ${ }^{47}$ The judge engaged in constitutional construction can have no law to work with beyond the Constitution itself. ${ }^{48}$

The exponents of constitutional construction have suggested a number of very general factors that ought properly to inform the process of construction. One prominent theme is that construction should work out the large values that underlie the constitutional text. Lieber described construction as "the drawing of conclusions respecting subjects, that lie beyond the direct expression of the text, from elements known from and given in the text."49 Jack Balkin assumes that "constructions are always attempts at implementation" of the principles underlying the constitutional text and Randy Barnett declares construction to be "guided" by the text's "general or abstract principles." 50 For example, after reading the Ninth and Fourteenth Amendments, Barnett concludes that one permissible constitutional construction requires placing a "burden on the government to show that its restriction on any liberty is both necessary and proper." This presumption

46 See, e.g., Page, supra note 12 at 543-51; Arthur L. Corbin, 5-24 CoRBIN ON ConTRACTs $\S 24.3$ ("Construction may produce a result which differs from the meanings that either or both parties assigned to the contract's terms.").

47 See Richard S. Kay, Original Intentions, Standard Meanings and the Legal Character of the Constitution, 6 CONST. COMMENT. 39, 48-49 (1989) (explaining that there can be no positive "law-behind-the-law" because the legal character of the Constitution is not attributable to prior law). In a recent article, The Law of Interpretation, 130 HARV. L. REv. 10709 (2017), William Baude and Stephen Sachs argue that there is a "law of interpretation" that dictates how a court is to understand all legal texts including the Constitution. They suggest that the application of this law can reduce the indeterminacy associated with modern ideas of constitutional construction. Id. at $1140-41$. It is an "unwritten law" that is to be inferred from legal practice. Id. at 1104-05. They do not, I think, adequately explain how this law gets its authority since they deny that it is an inference from the rules that were promulgated by the constitution-makers. Id. They do say that it is a form of "general law." Id. at 1137-39. The example they give of the application of such general law is Swift v. Tyson, 41 U.S. (16 Pet.) 1 (1842). In rejecting Swift and its general law, Justice Brandeis expressed the now prevalent positivist view that "law in the sense in which courts speak of it today does not exist without some definite authority behind it." Erie Railroad Co. v. Tompkins, 304 U.S. 64, 79 (1938) (quoting Black \& White Taxicab \& Transfer Co. v. Brown \& Yellow Taxicab \& Transfer Co., 276 U.S. 518, 533 (1928) (Holmes J., dissenting)).

48 See Colby, supra note 28 at 770-71 (Constitution by definition, cannot control constitutional construction); Randy E. Barnett, Welcome to the New Originalism: A Comment on Jack Balkin's "Living Originalism", 7 JERUSALEM REV. OF LEG. STUD. 42, 47 (construction based on principles "disembodied from the text").

49 Lieber, supra note 8 at 56

50 Jack Balkin, Living ORIGINALism 180 (2011); RANDY E. BARNETT, RESTORING THE LOST CONSTITUTION: THE PRESUMPTION OF LIBERTY 124 (rev. ed. 2014) (Randy E. Barnett \& Restoring, eds.). See also id. at 126 ("In this way, constitutional construction, though not deducible immediately from the text, still may properly be connected to or constrained by it."). 
arises even though there is no single rule or set of rules in the constitutional text that clearly requires it. ${ }^{51}$

As Balkin puts it, "we must try to determine what principles underlie the text in order to build constructions that are consistent with it"; those principles, however, "are not limited to specific conceptions that the framers and ratifiers actually sought to endorse." 52 In sum, there is a relationship between text and construction, but it is both imprecise and intrinsically controversial. Construction "produces" legal norms that are not in the text, only associated with it. ${ }^{53}$

The possibilities of constitutional construction, therefore, are wide. The underlying "values or principles" of the Constitution tend to be discovered at high level of generality. As such, they are, by themselves, incapable of specifying results in litigated cases. To decide specific cases, practitioners of constitutional construction supplement them by applying some "normative theory for how to construe a constitution when its meaning runs out. There is no escaping this." ${ }^{4}$ By hypothesis, this "normative theory" is not uniquely determined by the constitutional text. Lawrence Solum makes this clear. Interpretation is a matter of "fact." But

[c]onstitutional construction is not driven by facts in the same way. Rather, construction is essentially driven by normative concerns. There may be disagreements about what kinds of norms are relevant and whether those norms should be considered on particular issues in particular cases, or whether the relevant norms operate systematically. Moreover, some theories of constitutional construction may be driven by considerations of political morality, whereas other theories may look to norms that are internal to legal practice. The abstract fact that construction is essentially normative does not entail any particular account of the norms that ought to govern the practice of construction. ${ }^{55}$

Construction, that is, necessarily requires "judgments and choices." As the quotation above indicates, Solum, who has offered the most extensive and thorough treatments of construction, provides little guidance for evaluating competing techniques of construction. Indeed, he says "the important point is that there are several possible approaches to the construction zone

51 BARNETT, RESTORING AT 261-68; Randy E. Barnett, Is the Constitution Libertarian? 2008-09 CATo SuP. CT. REV. 9, 25-26.

52 BALKIN, LIVING ORIGINALISM at 14, 260.

53 Lawrence B. Solum, Communicative Content and Legal Content, 89 NoTRE DAME L. REv. 479, 479-80 (2013). See also id. at 501 ("The constitutional doctrines that are associated with the phrases have legal content that is richer than the communicative content of the provisions in which the phrases occur."). For a sampling of the kinds of practices having varying degrees of connection with the constitutional text that might lay claim to the title "construction", see Ethan J. Ranis, Note, Loose Constraints: The Bare Minimum for Solum's Originalism, 93 TEX. L. REv. 765, 773-76 (2015).

54 Barnett, Interpretation at 70. See also Solum, Interpretation-Construction at 104; Lawson, supra note 1 , at 815-16.

55 Solum, Originalism at 472 (emphasis added).

56 Whittington, Constructing at 121-22. 
[Vol. 19:

that are consistent with the core commitments of originalism. .."57 In keeping with this understanding, Jack Balkin has identified eleven kinds of appropriate argument - arguments from "text . . . structure . . . purpose . . consequences . . . precedent . . conventi on ... custom ... natural law ... national ethos... political tradition ... [and] honored authority" - any or all of which may be plausibly employed in arriving at a given construction. ${ }^{58}$

We need to remember what this entails. "Constitutional" adjudications bind the state - in all its manifestations - and everyone else. ${ }^{59}$ When judicial decisions are founded on constructions, however, they are not "textual imperatives." ${ }_{60}$ Instead, as one critical analysis accurately puts it, judges in matters of construction are deemed to have "discretion to resolve ambiguities and vague terms based on extra-constitutional considerations." 61 Each judge must select what he or she decides is the appropriate "normative theory." Admittedly, such a theory will be connected in one way or another to the constitutional text. Inevitably, however, it will also be determined, in more or less substantial part, by the judges' own estimation of the right principles that ought to govern society ${ }^{62}$ In the case of judgments of constitutional courts of last resort those decisions will be unreviewable. Balkin puts it clearly: The "courts [may] require the political branches to act within a set of principles, rules, and reasons that courts construct in order to maintain their legitimacy and the legitimacy of the political system." 63 Courts thus act not just as law-appliers but as independent formulators and enforcers of political values. They add "an additional supermajoritarian requirement to . . . American democracy." ${ }^{4}$

Insofar as construction is conceptually independent of interpretation, one can, without self-contradiction, first practice an originalist method of interpretation and then go on to the distinct activity of construction. But it does not follow that adjudication founded on construction is "consistent

57 Solum, Originalism at 473.

58 Jack Balkin, The New Originalism and the Uses of History, 82 FORD. L. REv. 641, 659-60 (2013) (hereinafter Balkin, New Originalism).

59 Cooper v. Aaron, 358 U.S. 1, 18 (1958) ("[T] he federal judiciary is supreme in the exposition of the law of the Constitution, and that principle has ever since been respected by this Court and the Country as a permanent and indispensable feature of our constitutional system.").

60 WhitTington, Constitutional Construction at 8.

61 John O. McGinnis \& Michael B. Rappaport, Original Methods Originalism: A New Theory of Interpretation and the Case against Construction, 103 NW. U. L. REv. 751, 752 (2009).

62 Solum says that recognition of significant opportunities for constitutional construction "does not entail the conclusion that individual judges have discretion to make decisions based on their own views of political morality." He then lists at least five possible approaches to construction not including "theories ... driven by considerations of political morality" (see the quotation in text at note 55 supra) and acknowledges that there are and will continue to be "disagreements about the best approach." Solum, Originalism at 523.

63 BALKIN, LIVING ORIGINALISM at 301.

$64 I d$. at 326. 
with the core commitments of originalism." ${ }^{65}$ If it is anything, originalism is the belief that public power should be controlled mainly, if not exclusively, by application of the rules of the original constitution. ${ }^{66}$ But, by definition, binding decisions emerging from constitutional construction must be founded on considerations not exclusively derivable from the original constitution. As Mike Rappaport has concluded: "If the Constitution is defined as the original meaning of the words in the document-the standard definition of originalists - . . the judge who decides a matter in the construction zone is not deciding the matter based on the Constitution." ${ }^{67}$ The breadth of options that might lay claim to the label of constitutional construction, moreover, is in tension with the constraint and rule-of-law values that are usually associated with originalism. ${ }^{68}$

Solum has properly asserted that originalists must, at a minimum, recognize a "Constraint Principle," namely that "constitutional actors (e.g. judges, officials, and citizens) ought to be constrained by the original meaning when they engage in constitutional practice." ${ }^{69}$ It is no accident, therefore, that Randy Barnett first articulated his version of construction in an article entitled "An Originalism for Nonoriginalists." "0 Keith Whittington makes this contrast explicit, noting the option of "supplement[ing] originalist constitutional interpretation with nonoriginalist constitutional construction." 71 In the context of constitutional adjudication, the endorsement of constitutional construction amounts to the "view that courts are authorized to impose constitutional rules other than those adopted by the constitutional [enactors]," a position that more or less defines nonoriginalism. ${ }^{72}$

65 Solum, Originalism at 473 (emphasis added).

66 Solum puts the matter in a slightly looser form. "Almost all originalists agree that the original meaning ought to make a substantial and important contribution to constitutional doctrine, and most originalists make the stronger claim that this contribution ought to constrain constitutional doctrine (absent very good reasons for departure from the original meaning)." Lawrence Solum, What is Originalism? The Evolution of Contemporary Originalist Theory in THE CHALLENGE OF ORIGINALISM: THEORIES OF CONSTITUTIONAL INTERPRETATION 12, 36 (Grant Huscroft \& Bradley W. Miller eds., 2011).

67 Mike Rappaport, Does a Judge Who Decides a Matter within the Construction Zone Enforce the Constitution? A Question About Construction, ONLINE LIBRARY OF LAW \& LiBERTY (Aug. 4, 2015), http://www.libertylawsite.org/2015/08/04/does-a-judge-who-decides-a-matter-within-theconstruction-zone-enforce-the-constitution-a-question-about-construction/.

68 See Colby, supra note 28 at 749-51; Richard S. Kay, "Originalist" Values and Constitutional Interpretation, 19 HARV. J. L. \& PUB. POL. 335 (1996).

69 Solum, Originalism at 456.

70 Randy E. Barnett, An Originalism for Nonoriginalists," 45 Loy. L. REv. 611 (1999).

71 Keith E. Whittington, Originalism: A Critical Introduction, 82 FORDHAM L. REv. 375, 403 (2013)(hereinafter Whittington, Critical). See also Mitchell N. Berman \& Kevin Toh, On What Distinguishes New Originalism From Old., 82 ForDHAM L. REV.545, 556, 568, 568 n. 76.

72 Whittington, Critical at 408. "There can be no originalist answer to the question of which construction to apply; by definition, construction supplements interpretation and cannot be dictated by it." Colby, supra note 28 at 734. On the affinity of the "new originalism" to "nonoriginalist" interpretation see James E. Fleming, The Inclusiveness of the New Originalism, 82 FORD. L. REV. 


\section{THE INESCAPABILITY OF CONSTITUTIONAL CONSTRUCTION}

Central to constitutional construction is the peculiar assumption that there are controversies that are, at the same time, controlled by the Constitution but for which the Constitution provides no rule of decision. It contemplates, that is, adjudications the binding force of which are premised on the constitutional text but which are decided, at least in part, on the basis of extra-textual considerations. It is hard to reconcile this picture of constitutional decision-making with the traditional American theory (although perhaps not the traditional practice) of constitutional adjudication. That theory is usually associated with Chief Justice Marshall's opinion in Marbury $v$. Madison. ${ }^{73}$ Constitutional judicial review was legitimized in that judgment solely as a vindication of the authority of the constitutional text. "[C]ourts as well as other departments are bound by that instrument." A court may only "say what [that] law is."74

Constitutional construction, on the other hand, presumes that the text cannot determine for the judge "what the law is." It lacks the resources to enable a court to move seamlessly from the moment of interpretation to the moment of construction. So, Keith Whittington has stated that a "precondition" of construction is for "parts of the constitutional text [to] have no discoverable meaning." 75 "There will be occasions when the Constitution as written cannot in good faith be said to provide a determinative answer to a given question. This is the realm of construction. ..." ${ }^{76}$ Randy Barnett asserts that the constitutional text does not always contain "enough information to resolve a particular issue without something more." 77 Sometimes this deficiency is premised on the limited substantive scope of the written rules. ${ }^{78}$ More often, however, it is based on the inherent uncertainty of constitutional language. Such language might rule out certain applications but others will remain intrinsically controvertible. So Barnett poses rhetorical questions: "What is a 'reasonable' search? For that matter, what exactly is a "search?",79

The idea that constitutional construction is inevitable, therefore, follows from assumptions about the practical limits of constitutional interpretation.

433 (2013)(discussing changes in the landscape of constitutional theory from 1996 to 2013); Peter J. Smith, How Different Are Originalism and Non-Originalism? 62 HastingS L.J. 707 (2011).

5 U.S. (1 Cranch) 137 (1803)

Id. at 177.

WhitTington, CONSTITUTIONAL CONSTRUCTION at 7. This and the following quotations were directed specifically at the United States Constitution. There is no reason, to think, however that the same assertions might not be made about any constitutional text.

Whittington, Constructing at 121

Barnett, Interpretation at 67.

See Whittington, Constructing at 130

Barnett, Interpretation at 68-69. See text at notes 82-88 infra. 
The proponents of constitutional construction all subscribe to an originalist method of interpretation, one that directs interpreters, and especially constitutional courts, to identify and apply the "original meaning" of the constitutional text. These advocates of construction have necessarily decided that an investigation of original meaning will often be inadequate to decide certain controversies. ${ }^{80}$ According to Solum, "if our best interpretation yields underdeterminate communicative content, then we need to do something and by definition that something will be construction." 81

This conclusion, however, depends on a prior assumption about how we identify "original meaning." It presupposes that the object of interpretation is the meaning the relevant language would have held for some hypothetical speaker and reader of English at the time that the provision at issue was enacted. This understanding is sometimes called "original public meaning" originalism and sometimes "new originalism." But while widely held, this position is controversial even among originalists. As the label, "new originalism" suggests, there is also an "old originalism." That version looks for the meaning that was actually held by the particular human beings whose assent made the Constitution law. ${ }^{82}$ The "new originalists," on the other hand, emphatically exclude any inquiry into the actual intentions of the constitution-makers. Meaning is to be inferred exclusively from the text understood against the linguistic and political background of the time of its utterance.

There is a crucial relationship between the "new originalist" choice of textual over intended meaning and the claimed necessity of constitutional construction. A text considered by itself will very often be compatible with more than one possible meaning. Only one of those meanings, however, will coincide with the communicative intention of the text's author. Kent Bach has noted the "truism" that "linguistic meaning generally underdetermines speaker meaning." 83 The academic explication of constitutional construction generally assumes two different kinds of linguistic uncertainty_-vagueness and ambiguity. ${ }^{84}$ "Ambiguous" language has two possible

80 See Gary Lawson, Dead Document Walking, 92 B.U. L. REV. 1225, 1232 (2012)(hereinafter, Lawson, Dead Document).

81 Lawrence Solum, Thoughts About Rappaport's Question About Construction, LEGAL THEORY BLOG, (August 6, 2015), http://lsolum.typepad.com/legaltheory/2015/08/thoughts-aboutrappaports-question-about-construction.html.

82 See Richard S. Kay, Original Intention and Public Meaning in Constitutional Interpretation, 103 Nw. U. L. REV. 703, 714-19 (2009) (hereinafter Kay, Original Intention) and authorities cited. On the identification of the original enactors see Richard S. Kay, Adherence to the Original Intention in Constitutional Adjudication: Three Objections and Responses, 82 NW. U. L. REV. 226, 229-36 (1988) (hereinafter Kay, Adherence).

83 Kent Bach, Context ex Machina, in Semantics vs. Pragmatics (ed. Zoltan Gendler Sabo, 2005) $15,16,26-27$.

84 Lawrence Solum, Legal Theory Lexicon, 051, Vagueness and Ambiguity, http://Isolum.typepad.com/legal_theory_lexicon /2006/08/legal_theory_le_html. 
but clearly distinct meanings. Context, will usually be sufficient to make one of those meanings inapposite in a certain text without further recourse to an investigation of what the authors actually intended. ${ }^{85}$ Language exhibits "vagueness," on the other hand, when its meaning is unclear because the exact boundaries of its referent are undefined. Words like "tall" or "bright" or "faithful" fall into this category. The Fourth Amendment to the United States Constitution barring "unreasonable searches and seizures" is a vague constitutional term. The uncertainty associated with a vague expression appears as soon as we inquire whether a particular thing or activity is or is not covered by the rule containing it. Just knowing how certain words were generally used at the time of utterance might rule some alternatives in or out. ${ }^{86}$ But there will be many cases in which that information by itself will be insufficient to reach such a conclusion. It is not just that we don't know enough about standard usage at the relevant time. Even if we knew everything there was to know about linguistic practice, we would still be at a loss to say whether certain acts were or were not within a rule's extension. Consequently, "original meaning is bound to run out when the semantic content of the Constitution is vague." 87 Rule appliers will then turn to construction.

Many provisions of the United States Constitution will yield reasonably determinate rules when examined in context. In those cases, there will be little room for construction. For the most part, however, disputes about these more precisely specified terms rarely come to litigation. It is the oth$\mathrm{er}$, the vague kind of textual provision-freedom of speech, due process, reasonable search - that spawns the greatest volume of constitutional disputes. It follows that creative judicial constitutional construction will not be the exception. It will be the usual method of constitutional adjudication. ${ }^{88}$

85 Solum, supra note 1 . There may be rare cases of "irreducible ambiguity" where these resources are inadequate to indicate the more likely correct of the two meanings. See Solum, Originalism at 470. Note, however, that when we do decide between the alternate possible meanings of an ambiguous term based on the surrounding context, we are likely to base that conclusion on what we think the typical reader would infer about what the writers of a legal text must have intended when they used those words in that kind of communication. See Steven Knapp \& Walter Benn Michaels, Not a Matter of Interpretation, 42 SAN DiEGo L. REV. 651, 654-56 (2005).

86 See Randy E. Barnett, The Misconceived Assumption about Constitutional Assumptions, 103 Nw. U. L. REV. 615, 634-36 (2009) [hereinafter Bamett, Assumptions].

87 Lawrence B. Solum, Legal Theory Lexicon 063: Interpretation and Construction, LEGAL THEORY LEXICON, http://lsolum.typepad.com/legal_theory_lexicon/2008/04/legal-theory-le.html (last modified Sept. 3, 2015). See also Lawrence B. Solum, The Fixation Thesis: The Role of Historical Fact in Original Meaning, 91 NOTRE DAME L. REV. 1, 61 (2015) [hereinafter Solum, Fixation]. Solum, Originalism at 470; BARNETT, RESTORING at 122; Colby, supra note 28 at 732.

88 See, e.g., BALKIN, LIVING ORIGINALISM at 104; BARNETT, RESTORING at 396 ("[I]n $99.9 \%$ of constitutional cases courts are engaged in constitutional construction ..."); Randy E. Barnett, Trumping Precedent with Original Meaning: Not as Radical as It Sounds, 22 CONST. COMM. 257, 263 (2005) [hereinafter Barnett, Trumping]. See also Smith, supra note 72, at 709, 734; 
This conclusion, however, follows only because of the new originalist decision to reject intended meaning for public meaning. ${ }^{89}$ If we adopted the "old originalist" inquiry into the meaning actually intended by the human beings whose assent made the Constitution law, identification of the correct meaning even of vague language looks much more practicable. That is because the resources for defining the boundaries of the vague terms would be substantially enhanced. ${ }^{90}$ We know the constitutionmakers wanted to accomplish something when they enacted a rule. They used language to mark out a category of actions for regulation or prohibition because they held certain beliefs about the best way to structure and limit the government. They must have understood those words to signify things or categories of things that had certain characteristics that they believed called for this treatment. An examination of the historical and political context of that decision and the reasons for it that were expressed by the enactors provides much more information than an inquiry limited to "contemporary dictionaries, grammar books, and other indicia of public meaning." 91 We can derive a picture of actually intended meaning that is qualitatively richer than one inferred from an investigation that is restricted to standard language use at the time of enactment. ${ }^{92}$

This more fruitful source of textual meaning is especially significant in the context of constitutional litigation. Courts are never obliged to formulate some single, correct meaning of a term in the constitutional text. They need only decide which of two meanings proffered by contending litigants is more likely correct: Is stopping and frisking someone on reasonable suspicion that he or she is armed and dangerous an unreasonable search within the terms of the Fourth Amendment-or is it not such a search? ${ }^{93}$ Given the wealth of information available about the evils that concerned that Amendment's enactors, a competent judge will almost certainly be able to make an honest decision that one or the other claim about the scope

Robert J. Delahunty \& John Yoo, Saving Originalism, 113 MICH. L. REV. 1081, 1098 (2015) ("[C]onstruction plays a critical role - perhaps even the leading role - in constitutional adjudication.").

89 Heidi Kitrosser, Interpretive Modesty, Minnesota LEGAL STUDIES RESEARCH PAPER No. 14-34 1, 2, 31-32 (2014), http://ssm.com/abstract=2463366.

90 This kind of meaning was taken for granted by the first self-conscious originalist scholars. See Kay, Original Intention at 704-05. This "intentionalist" version of originalism is defended for independent reasons. Id.. at 712-25; Larry Alexander \& Saikrishna Prakash, "Is That English You're Speaking?" Why Intention Free Interpretation Is an Impossibility, 41 SAN DIEGO L. REV. 967, 974-82, 992-93 (2004).

91 Steven G. Calabresi \& Andrea Matthews, Originalism and Loving v. Virginia, 2012 B.Y.U. L. REV. 1393, 1394 (2012). An inquiry into the original intentions of some apparently vague terms might also show that they were intended in a narrower, technical legal sense. See John O. McGinniss \& Michael B. Rappaport, The Abstract Meaning Fallacy, 2012 U. ILL. L. REv. 737, 749-750 (2012).

92 See Kay, Adherence at 250-59.

93 Terry v. Ohio, 392 U.S. 1 (1968). 
of the rule is more probably correct. So even if "historical evidence will not tell you whether the thermal imaging of a house is or is not a search," 94 it may tell you whether the proposition that it is a search within the intended meaning of the Fourth Amendment is more or less probable than the proposition that it is not. A judge's confidence about such a conclusion, of course, will differ in different circumstances. But with the exception to be discussed below, the relevant historical evidence of the intentions of the enactors is sufficiently dense that it will almost never result in a "tie." "95

It is true that there may be one situation where available evidence will fail to identify a better answer to a disputed question of intended meaning. That is when there is no information at all as to whether or not a challenged action falls within the intended scope of the text relied on. Most prominently, there might be cases where the action at issue did not exist and could not have been foreseen by the people who made the Constitution. Of course, no one would contend that something is not regulated by the constitutional text just because we think the enactors did not have that very thing in mind in when the Constitution was enacted. Like all legal rules, the provisions of the Constitution describe categories of action. ${ }^{96}$ As noted, the extent of such a category, depends on the characteristics that the constitution-makers understood to define the criteria for inclusion or exclusion. It requires no construction to conclude that television news is protected by "freedom of the press" or that torture by application of electric current is a prohibited "cruel and unusual punishment."97

We might imagine a case where the challenged activity is so different from anything the enactors could have contemplated that it will be impossible to say that it was or was not in any of the regulated or prohibited categories that they promulgated. But even in such a case, it does not follow that the activity is neither permitted nor prohibited by the Constitution understood according to the intentions of its creators. Constitutional provisions are of two types. Sometimes they create legal agencies and define the extent of their authority, implicitly prohibiting the exercise of any other power. Alternatively, they may recognize the prior existence of some entities and merely impose certain limits on their activities. The appropriate forms of constitutional argument depend on the kind of constitutional rule

94 Barnett, Interpretation at 71.

95 See Kay, Adherence at 243-45, 254; Lawson, Dead Document at 1233. McGinnis \& Rappaport, supra note 91 at 773-75.

96 See Frederick Schauer, Playng By THE RULEs 23-24 (1991).

97 I therefore disagree with Randy Barnett's statement that "[ $\mathrm{t}$ here can be no purely historical answer" to questions about the meaning of a constitutional term when "the object to which the term is applied did not exist at the time of the framing." BARNETT, RESTORING at 122. The process of identifying the particular category of actions intended to be covered by broad constitutional terms is similar to what Solum calls "original conception interpretation." Solum, Fixation at 5356. 
being invoked. When the argument is about the first kind of rule, anyone defending a challenged act by the constitutionally created institution will have to show that it falls within the authority granted. In contrast, an argument about the authority of a pre-existing but constitutionally limited entity will require the challenging party to demonstrate that the act in question was one withdrawn by the Constitution.

The enactors of the 1787-1789 Constitution made clear their intention that the government of the United States was to be regulated mainly by the first kind of rule. They thought, that is, that all of that government's power was created and defined by the Constitution. In defending the proposed Constitution, for example, James Wilson, one of its drafters, emphasized the difference, from the point of view of that constitution, between the states, "invested ... with every right and authority which [the people] did not in explicit terms reserve" and the new federal government in which "the reverse of the proposition prevails, and everything which is not given, is reserved." 98 The Founders never tired of repeating that the Constitution established a federal government of "enumerated" powers and that those powers were "few and defined." 99 On top of this scheme, however, the enactors added some constitutional rules of the second kind, imposing some specific limitations, on the granted powers,. Individual rights provisions are the most obvious examples. It was fear that the creation of such constitutional rights might obscure the more fundamental restriction of the United States government to the enumerated powers that stimulated the constitution-makers to restate that principle with emphasis in the Ninth and Tenth Amendments. ${ }^{100}$ The second kind of rule was also employed in the United States Constitution to limit the actions of the presumed and otherwise unregulated powers of the state governments. ${ }^{101}$

With this background, we can return to the claim that there are some things about which the rules of the Constitution, interpreted according to the original intentions, have nothing to say. Constitutional litigation challenging an action of the federal government can take only two forms corresponding to the two kinds of rules just described. In the first, the claim is that the government has exercised a power not granted to it by the Constitution. Since the Constitution presumes that the federal government only has such power as the Constitution gives it, a challenge to a federal exercise of

98 James Wilson, State House Yard Speech (Oct. 6, 1787), reprinted in COLLECTED WORKS OF JAMES WILSON 171, 171-72 (Kermit L. Hall \& Mark David Hall, eds., Liberty Fund 2007).

99 The Federalist No. 45, at 289 (James Madison); No. 39, at 234 (James Madison); No. 14, at 97 (James Madison) (Clinton Rossiter ed., 1961).

100 See Thomas B. MCAFFe, InHEREnt Rights, the Written Constitution and Popular SOVEREIGNTY $83-88$ (2000). Obviously, these citations are merely illustrative. I find the evidence for the proposition that this was the way the enactors understood the Constitution to be conclusive. 
power may only be rebutted by identifying the relevant granted power and showing that it covered the action in contest. If we are, by hypothesis, incapable of concluding anything about whether the constitution-makers' intended meaning did or did not extend to that action, it will be impossible to make that showing. In such a case, therefore, a court would have to conclude that the government was without constitutional power to perform the challenged act. The second kind of constitutional claim will concede that the action in question was within a granted power but will nonetheless assert that the particular exercise of that power transgressed some affirmative limit included in the constitutional text. The same reasoning now applies to the challenging party. If there is no information at all about the intended meaning of the cited rule insofar as it applies to the relevant facts, a party will be unable to show that the rule limited the granted power in the way claimed. A court in such circumstances will be obliged to reject the constitutional claim. While this reasoning applies most naturally to the listed legislative powers of Congress and the explicit limits to those powers, it is equally true for every granted power and every prohibition, including those relating to the executive and judicial branches. ${ }^{102}$

This reasoning applies equally to cases where the activity of a state is alleged to violate the United States Constitution. States were understood by the enactors to have authority that was prior to and independent of the federal constitution. ${ }^{103}$ They would, however, be subject to that constitution's affirmative limits on their conduct. They may not, for example, impair the obligation of contract or deprive a person of liberty without due process of law. Someone arguing that a state has violated the Constitution, therefore, must show the state's conduct was within such a limiting rule. Again, if there is no information at all about whether or not that rule includes the action in question, a court would be obliged to hold it constitutional. ${ }^{104}$

102 Gary Lawson made a similar argument restricted to federal and state powers. See Lawson, Dead Document at 1234-35.

103 Of course, states that did not exist at the time the United States Constitution was enacted came into being through a procedure that is itself prescribed in it. Once created, however, and from the Constitution's own point of view, such states are treated as possessing powers identical to those of the original states and not as exercising some kind of granted or delegated power. Puerto Rico v. Sanchez Valle, No. 15-108, slip op. at 11-12, n.5 (U.S. 2016); Coyle v. Smith, 221 U.S. 559, 573 (1911). Note, moreover, that state constitutions may apply to claims about state power in the same way that the federal Constitution applies to claims about the powers of the federal government. See Appeal of Norwalk St. Ry. Co., 69 Conn. 576, 584-90, 37 A. 1080, 1082-84 (1897).

104 I originally made this argument only in the context of the relative powers of state and federal governments under the United States Constitution. See Kay, Adherence at 256. Gary Lawson has taken a similar position. See, e.g., Lawson, supra note 1 at 834-36; Lawson, Dead Document at 1234-35. As the discussion in text indicates, however, its logic applies to actions by any entity once we have decided whether that entity's power is either wholly created by or is merely limited by the constitution that is invoked. 
It is important to stress that this reasoning does not depend on invocation of extra-constitutional "supplemental" or "default" rules. It is, in that respect, different from a "presumption of constitutionality" premised on the political propriety of judicial deference to the electorally accountable branches. ${ }^{105}$ That kind of presumption eliminates indeterminate cases but it does so based on propositions that are not themselves inferred from the constitutional text. ${ }^{106}$ In a recent essay, Lawrence Solum examined "default rules" advocated by Gary Lawson and Michael Paulsen, two public meaning originalists. Solum demonstrated that, contrary to the claims made for them, those rules could not be uniquely determined solely from consultation of the text and structure of the Constitution, even when undertaken in the context of its enactment. ${ }^{107} \mathrm{He}$ concluded that "these are normative arguments about the best construction and not linguistic arguments about communicative content." 108

In contrast, the assumptions about constitutional rules that I have outlined are not supplements to the Constitution. They are conclusions about the meaning of the Constitution. It is true that the bare constitutional text has "nothing that speaks to the general interpretive approach to be taken toward the document." 109 Once we consult the voluminous evidence of the original intentions, however, it is clear that these assumptions were part and parcel of the constitution-makers' design. ${ }^{110}$ The abundant historical mate-

The same reasoning would apply in the rarer cases when a constitutional rule is claimed to regulate the conduct of an individual. Constitutions presume the existence of, they do not constitute or define the powers of individuals. It will, therefore, be up to a claimant to show that a challenged individual action is within a proscription or in a field of regulation of a limiting constitutional rule.

105 See James B. Thayer, Origin and Scope of the American Doctrine of Constitutional Law, 7 HARV. L. REV. 129 (1893) (arguingthat courts should defer to legislatures and should only declare a legislative act unconstitutional if the act undoubtedly violates the constitution); ALEXANDER M. BICKEL, THE LEAST DANGEROUS BRANCH 183-97 (2d ed. 1986) (observing the Supreme Court's refusal to decide certain issues on political question grounds); Michael Stokes Paulsen, The Text, the Whole Text, and Nothing but the Text, So Help Me God: Un-Writing Amar's Unwritten Constitution, 81 U. CHIC. L. REV. 1385, 1395-96 (2014) (book review)(hereinafter Paulson, The Text) (arguing that, by default, the judiciary should defer to the legislature when reasonable minds could differ on a matter of constitutional interpretation); Lawson, supra note 1 at 834-36. For a helpful modern exposition of this view see MichaEL J. PERRY, COnstitutional Rights, Moral Controversy, AND the SuPreme Court 41-50 (2009).

106 See Whittington, Constructing at 127-28 (arguing that adopting a "clear mistake rule" is a political choice beyond the strict confines of the constitutional text).

107 See Solum, Originalism at 511-21 (assertingthat Thayerianism is not grounded in the constitutional text, but requires extra-legal normative justifications).

$108 I d$. at 521. In a subsequent publication, Paulsen explicitly refers to a default of deference to the political branches as a "construction." Paulsen, The Text at 1435-36; see also note 109 infra.

109 Whittington, Critical at 396 (2013)

110 Michael Paulsen argues that "where it cannot be said that the actions of the political branches are contrary to a rule of law supplied by exegesis of the text ... then the actions of the political branches must stand." Paulsen, The Text at 1437. This "construction" applies when constitutional language is "indeterminate," and may be "fairly discerned from the text itself." Paulsen, $I d$. at 
rial, makes clear that the Constitution was intended by its enactors to be an exclusive statement of the powers of the new government. ${ }^{111}$ Showing the contrary would require convincing evidence of real historical intentions. It would demand, that is, more than an inspection of English usage at the end of the eighteenth century. ${ }^{112}$

If we accept this interpretation of the Constitution, there will be no cases in which a court will be unable decide which of the two contested positions is more probably consistent with its rules. Either there will be evidence about the intended meaning that will point one way or the other or there will be no evidence and the nature of the constitutional allocation of power will decide the case. There will, of course, be cases where the amount and the force of evidence of the rule's intended meaning will be in contest. In such cases a court is obliged to make the best determination it can based on the available information. But there are no omitted cases, no litigated "constitutional issue on which the text [is] silent" and, consequently, no need for "construction [to] fill the gap." "113 At least in litigated cases, interpretation never "runs out." 114 We never require "something beyond interpretation in order to develop fully [the Constitution's] meaning." 115

This reasoning depends crucially on our ability to examine the Constitution's meaning by investigating the actual human intentions that underlay the choice of a cited constitutional rule or the nature of a constitutional allocation of authority. We can only make the necessary judgments if we are able to examine the dense historical record about what the constitutional enactors intended to accomplish when they approved the language of the rules invoked. The impoverished kind of reading enjoined by the advocates of "public meaning" originalism, on the other hand, will necessarily turn up many more cases where one meaning is no more probable than another. That is because there will be frequent cases in which both proffered

1436-37. The resulting rules for adjudication are similar to those I have outlined. But, as with the default rules criticized by Solum discussed in the text, this presumption cannot be deduced from an examination that is limited to the words of the Constitution. The "text, structure and logic" of the Constitution is consistent with a number of different and conflicting background rules including one that supposes that the Constitution's rules are to be treated as limits on a pre-existing plenary power. We know that the Constitution is a grant of exclusive powers to the United States but we know it only by examining the intentions of the human beings who enacted it.

111 So it is not enough to say, as Keith Whittington does, that "[i]t is possible that the Constitution does not include such closure rules or that any such supplementary interpretive rules that it does include are not complete." WHITTINGTON, CONSTITUTIONAL INTERPRETATION at 8 (emphasis supplied). As a matter of historical fact, American constitutions were intended to be and have been understood to be of the kind that I have described in the text.

112 It should be stressed that we only need to rely on this ground of constitutional decision-making in the rare cases where the evidence of the intended scope of the particular rule cited is insufficient to tell us whether one position or another is more probably within its extension.

113 Solum, Interpretation-Construction at 107.

114 Supra note 31.

115 Whittington, CONSTRuCTiOn at 7. 
meanings will be consistent with the language as it might have been understood by the reasonable English-speaker at the time of enactment. ${ }^{116}$ The distinction between vague and ambiguous terms which is so significant for the proponents of constitutional construction ${ }^{117}$ loses much of its salience once we abandon the idea that we are restricted to public meaning. There really may be no single public meaning of a vague provision; that kind of interpretation really may "run out." 118 When, in contrast, we ask about the intended meaning of a vague phrase, we can usually learn a great deal about the range of conduct its enactors wanted to regulate. With that knowledge we will be able to decide which of the proffered meanings is more consistent with the intended meaning of the text.

The preference for "new," original public meaning originalism and the need for constitutional construction are logically connected. Anyone embracing the former presumes an incomplete constitution and may need to look, in one form or another, to the latter to decide certain constitutional disputes. There will be, that is, frequent occasions on which courts will act on grounds that are not derived exclusively from the written constitution. ${ }^{119}$ We might, in fact, ask whether the possibility of such construction is not one of the main attractions of the public meaning approach. As noted, much modern American constitutional adjudication has been based on the "vaguest" provisions in the text. ${ }^{120}$ These terms can have no unique original public meaning and, therefore, they provide numerous opportunities for

116 Colby, supra note 28 at 732.

117 See supra text at notes 83-88; see also Barnett, Interpretation at 67-69; Solum, InterpretationConstruction at $97-98$.

118 Randy Bamett, The Gravitational Force of Originalism, 82 FoRDHAM L. REV. 411, 419 (2013).

119 This is hardly the only, or even the most important, trouble with public meaning originalism. The foremost difficulty is the necessary severance it works between the applied meaning and the political facts that make the constitution legitimate and binding. I discuss this and other problems attached to this form of originalism in Kay, Original Intention at 714-19. A clear recent recapitulation of this flaw is Richard Ekins, Objects of Interpretation, 32 CONST. COMM. (forthcoming Winter 2017).

I do not discuss here the claim that an originalism that adheres to the actual intentions of the constitution-makers is impossible and that, therefore, public meaning originalism is the only practical version on offer. Original intentions are claimed to be inaccessible because of the historical difficulties involved in reconstructing them, because it is impossible to collate the intentions of individual enactors in such a way as to identify a sensible collective intention for the adopted text or because it actually contradicts the enactors' interpretive intention - that their substantive intentions should not control. I have responded to these arguments more than once. See, e.g., Kay, Adherence at 236-59; Richard S. Kay, American Constitutionalism in ConstiTUTIONALISM: PHILosophical Foundations 16, 35-39 (Larry Alexander ed., 1998); Kay, Original Intention at 709-14. I do not believe my arguments on these questions have been refuted and, in fact, with rare exceptions, such refutations have not been attempted. A notable exception is Lawrence Solum's discussion of the problem of summing multiple intentions in Semantic Originalism 42-49 (Illinois Public Law and Legal Research Paper Series, Research Paper No. 07-24, 2008) https://ssrn.com/abstract=1120244. Solum's argument is serious but for reasons beyond the scope of this paper, I find it ultimately unconvincing. 
constitutional construction. The resulting judicial decisions have had and will continue to have a far-reaching impact on the shape and functioning of American political society. Public meaning interpretation and constitutional construction overtly commit those decisions to a judicial process that is "not primarily legal but political." 121 The factors that are suggested to define such constitutional construction are so general that they would be unlikely to impose any genuine restraint, even if some uniform version of them were adopted by constitutional judges. ${ }^{122}$ Indeed, in an early exposition, Keith Whittington opined that, since it was "not grounded in discoverable meaning," there were "genuine limits to the ability of rational argument to fulfill the needs of construction." 123

The consequence has been what one would expect. Academic practitioners of construction have described its applications in very different ways. Two serious constitutional scholars, Randy Barnett and Jack Balkin, came around to originalism only after public meaning interpretation and constitutional construction were available, allowing them to adopt it in this new malleable version. The resulting constitutional regimes they discovered have certain overlapping features. Mainly, however, they have arrived at starkly different catalogs of the powers granted to or withdrawn from American governments. Using the combination of public meaning interpretation and constitutional construction, Barnett concluded that the federal government was given a far narrower authority than the one commonly pictured in modern constitutional jurisprudence. The legislative reach of state governments would be similarly limited by a constructed presumption against any regulation that impinged on natural rights - including the right to hold and use property. ${ }^{124}$ Balkin, on the other hand, using basically the same tools-public meaning interpretation and constitutional constructionfound that the Constitution permitted a large, vigorous and adaptable welfare state on both state and federal levels. ${ }^{125}$ In each case, these visions largely coincided with the ones held by these scholars in their nonoriginalist days.

Public meaning constitutional interpretation/constitutional construction, therefore, seems to lead to a legal-political system the shape of which is, in

121 Whittington, Constitutional Construction at ix. But see Barnett, Restoring 124-27 (denying that constitutional construction guided by the Constitution's abstract values is political.)

122 See, e.g., BALKIN, LIVING ORIGINALISM at 14 (" $[\mathrm{W}]$ here the text offers an abstract standard or principle, we must try to determine what principles underlie the text in order to build constructions that are consistent with it .... Indeed, the fact that adopters chose text that features general and abstract concepts is normally the best evidence that they sought to embody general and abstract principles of constitutional law, whose scope, in turn, will have to be worked out and implemented by later generations.")

123 WhitTington, CONSTITUTIONAL CONSTRUCTION at 210.

124 BARNETT, RESTORING at 273-338, 369-89, 403-08.

125 LIVING ORIGINALISM supra note 50 at 138-82, 282-85, 317-19. 
the last analysis, substantially committed to a series of fresh political choices made by judges of the court of last resort. There are doubtless attractions to this model of public decision-making, one where our collective decisions are not constrained by an arguably out-of-date set of constitutional rules. Our social welfare might be enhanced by vesting power to modify the actions of politically accountable officials in an unelected group of experts who attempt to make those actions better conform to shared fundamental values. ${ }^{126}$ We should be clear, however, that this model is profoundly at odds with a central assumption of constitutionalism: Living under a constitution is supposed to provide some clear rules for what the state may and may not do to us. It is true that no theory of constitutional adjudication can eliminate all uncertainty about the precise reach of constitutional rules; even good faith inquiries into the intentions of the enactors of a constitutional text are sure to result in disagreements in close cases. But the intended meaning of constitutional provisions is a matter of genuine historical fact for which there will be objective, if not always conclusive, evidence. Constitutional construction, on the other hand, is essentially a process of decision-making that involves evaluation of the relative merits and weight of the broad historical and contemporary principles and values that are thought to underlie our social and political institutions. There simply is no fact of the matter about the correct construction applicable to a particular controversy. Constitutional construction, at its heart, puts its trust in human judgment not in historically fixed rules. This isnot to put too fine a point on it-the opposite of constitutionalism. It is at least incongruous that this state of affairs is to be administered citing the authority of the written constitution.

126 I put to one side the question of whether, if we had such guardians, we would seek out people with the characteristics typically found in appellate judges. 